IRSH 50 (2005), pp. 399-433 DOI: 10.1017/S0020859005002166

(C) 2005 Internationaal Instituut voor Sociale Geschiedenis

\title{
The International Trade-Union Movement and the Founding of the International Labour Organization*
}

\author{
REINER TOSSTORFF
}

Summary: Accounts of the founding of the International Labour Organization (ILO) usually emphasize the role of social-reformist intellectuals and politicians. Despite the indisputable role of these actors, however, the international labour movement was the actual initiator of this process. Over the course of World War I, the international labour movement proposed a comprehensive programme of protection for the working classes, which, conceived as compensation for its support of the war, was supposed to become an international agreement after the war. In I919, politicians took up this programme in order to give social stability to the postwar order. However, the way in which the programme was instituted disappointed the high expectations of trade unions regarding the fulfilment of their demands. Instead, politicians offered them an institution that could be used, at best, to realize trade-union demands. Despite open disappointment and sharp critique, however, the revived International Federation of Trade Unions (IFTU) very quickly adapted itself to this mechanism. The IFTU now increasingly oriented its international activities around the lobby work of the ILO.

Markku Ruotsila recently described the establishment of the International Labour Organization (ILO) in the spring of 1919 within the framework of the Paris Peace Conference as the result of an interaction between social-reformist intellectuals and politicians, in particular in the months after the end of World War I. ${ }^{\mathrm{I}}$ Likewise, in this issue Jasmien Van Daele emphasizes the interlocking context in which two important Belgian leaders, a social-reformist intellectual and a socialist politician, acted. These are all undoubtedly important moments in the overall

* The present article presents some findings from the research project "Trade-Union Federations as Transnational Actors: The International Federation of Trade Unions (IFTU) and Its Influence on the International Labour Organization (ILO) Between the Two World Wars" ["Gewerkschaftsdachverbände als transnationale Akteure: Der Internationale Gewerkschaftsbund (IGB) und sein Wirkungsfeld in der Internationalen Arbeitsorganisation (IAO) in der Zwischenkriegszeit"]. This project has been financed by the Deutsche Forschungsgemeinschaft. I would like to thank the anonymous reviewers for this journal for their critical remarks on the first draft.

I. Markku Ruotsila, "The Great Charter for the Liberty of the Workingmen: Labour, Liberals and the Creation of the ILO", Labour History Review, 67 (2000), pp. 29-47. 
process. Already in 1934, James T. Shotwell, ${ }^{2}$ who participated on the American side in the I9I9 negotiations, provided a broad account of the prehistory and genesis of the ILO. However, in his work Shotwell presented governments as the main protagonists, concentrating on the discussions in Paris and the formation of the ILO at the first labour conference in Washington in November 1919. By contrast, this article will focus on the role of the international trade-union movement and its continuous efforts, beginning in 1916, to establish an international labour organization. In so doing I will take into account the rivalry between the two camps that emerged in the international trade-union movement during World War I.

The trade-union federations were the real driving force that pressured governments to include a social-policy programme in the peace treaty after the war. This represented a new development in international relations, although it did build on initial international social agreements from prior to World War I. In addition, these trade-union initiatives were warmly welcomed by social-reformist intellectuals, who had themselves long provided active support, as the two aforementioned articles emphasize. The creation of the ILO as part of the postwar order, in other words, emerged from the confluence of these various factors. Although the trade unions, given the high expectations fostered by the political climate of I919, were not completely satisfied with the actual result, they quickly accepted the situation and became the mainstays of the ILO. This marked a change from the way in which they had perceived themselves before I9I4: they were no longer content to limit themselves to the exchange of information, but wanted to become international players.

When I refer to the "international trade-union movement" here I mean primarily the International Federation of Trade Unions (IFTU). The IFTU, which was the merger of socialist, and in part syndicalist, national trade-union federations, was founded in I90I as the "International Secretariat" and then renamed in I9I $3 .{ }^{3}$ From the outbreak of World War I, however, the IFTU had been paralysed. The organizations in the Entente resp. Allied camp denied the legitimacy of its leadership, which was controlled by the German trade unions, whose chairman, Carl Legien, was also the IFTU president. Consequently, the international meetings

2. James T. Shotwell (ed.), The Origins of the International Labor Organization, 2 vols (New York, 1934) [hereafter Origins].

3. On this history, see the relevant sections by Michel Dreyfus and Geert Van Goethem in Anthony Carew et al., The International Confederation of Free Trade Unions (Berne, 2000), pp. 25-I63. Van Goethem is also the author of a dissertation, at present only available in Dutch, on the IFTU: De Internationale van Amsterdam. De wereld van het Internationaal Vakverbond $(I V V), 1913-1945$ (Antwerp-Ghent, 2003). For a brief overview, see also Reiner Tosstorff, Kurze Geschichte des Internationalen Gewerkschaftsbundes. 85 Jahre Amsterdamer Internationale (Hamburg, 2004). 
during the war, which resulted in the initiative that led to the foundation of the ILO, as well as the meetings immediately after the war were not technically IFTU meetings, at least not those of the Entente camp. At the same time, both trade-union camps fought for hegemony over the tradeunion federations of the neutral countries.

The international Christian trade-union movement remained only a marginal force in this process. First of all, it was far weaker than the IFTU, and prior to World War I its international structure was very loose. Not until April I 9r 9 did the Christian trade-union movement again try to unite into an international movement, in large part due to the social-policy discussions at the time. However, these efforts remained in the incipient stages so that it had no influence at all. In addition, differences in the Christian camp remained irreconcilable. Its worker delegates recognized their marginal position at the first ILO conference in November 1919, and this led to the formation of the International Federation of Christian Trade Unions (IFCTU). (They then sought to participate actively in the ILO, but were never able to achieve more than a minority status; their relationship with the IFTU was at times quite competitive and combative.) Thus, one could say that the ILO acted here as a godfather at the establishment of the IFCTU, whereas the IFTU, on the contrary, played a decisive role in the founding of the ILO. 4

The current article, however, will focus solely on the question of international social policy, its substance, and the creation of an institutional framework for it. Broader questions of particular war aims (such as territorial demands and reparations) or of a comprehensive framework for peace (which culminated in the idea of a League of Nations) cannot be addressed here. For this reason, I examine only the discussions of the international trade unions, leaving aside the "labour and socialist conferences" that took place on the Allied side in I9I8. These latter meetings dealt with international social policy as one issue among many, essentially repeating the demands made at the trade-union conferences. Their first priority was the general question of war goals, i.e. the structure of the postwar order in accordance with a "Wilsonian peace". Moreover, it would transcend the scope of this article to take into account "political" participants, without adding significantly to our knowledge of the development of the ILO or of the trade-union movement's contribution to this process.

Unfortunately, it has been practically impossible for the author to rely on archival documents from trade unions, since most of this material no

4. See Bernhard Otte, "Internationaler Bund christlicher Gewerkschaften (IBCG)", in Ludwig Heyde (ed.), Internationales Handwörterbuch des Gewerkschaftwesens, vol. I (Berlin, I 93 I), pp. 817-823; Patrick Pasture, Histoire du syndicalisme chrétien international. La difficile recherche d'une troisième voie (Paris, I999). 
longer exists (or exists only in fragments). The IFTU archive disappeared during the German advance on Paris in I940; a number of trade-union federations, such as the British General Federation of Trade Unions, simply disposed of their own records at some point as waste paper.

\section{THE LEEDS PROGRAMME ( I 9 I 6 )}

Already at a convention in November I9I4, when the United States was still neutral, the American Federation of Labor (AFL) demanded that the international trade-union movement have an important say in structuring the postwar order.5 The AFL called for an international trade-union conference, which was to be held parallel to the inevitable peace talks and influence their conclusions. The demand that a new international order be based on principles such as disarmament, the establishment of courts of arbitration to settle international disputes, etc. undoubtedly reflected a widespread conviction in the international trade-union movement. But to what extent should a peace treaty contain specific worker demands and conditions for social policy?

At the outbreak of World War I, almost all trade-union federations in Europe and North America were part of the IFTU, which had its headquarters in Berlin. Before I9I4, its president, Legien, had declared all general issues to be beyond the competence of the IFTU. Rather, such issues were to be the responsibility of the Party or the Second International. Here, Legien followed the German model, which was based on the Marxist-social-democratic division of labour between the Party and trade unions.

This position affected not only explicit political problems such as disarmament, but also the question of an international social policy. After numerous debates and even initial conferences over the course of the nineteenth century, the International Association for Labour Legislation (IALL) was created in $\mathrm{I} 900$ as an association of social-reformist intellectuals. The IALL, in turn, established an International Labour Office with headquarters in Basle. This was not an international organization with officially binding powers, although it was financed by various European states. It was supposed to provide advice and disseminate information on social policy. Through expert consultations, the International Labour Office initiated two international agreements, which were accepted by a diplomatic conference in 1906 (the prohibition of night shifts for women and the prohibition of the use of white phosphorous in matchstick production). Independent of this, there was also series of bilateral agreements between individual countries, which primarily 
addressed problems arising from immigration. Further initiatives were in preparation when war broke out. The IFTU did not contribute to these efforts, since it did not regard participating in the deliberations as part of its responsibilities. However, an increasing number of national trade-union federations did send prominent representatives to participate in the national sections of the IALL. ${ }^{6}$

But now the international trade-union movement's lack of interest in such issues disappeared with the emergence of discussions about influencing a peace treaty. It was no coincidence that the Entente trade-union organizations, and not Legien or the IFTU, took the first step. The Entente organizations mainly followed the syndicalist or trade-union model ${ }^{7}$ and, already prior to World War I, had rejected a simple division of labour between politics/party and economy/trade union. However, given the extraordinary organizational power of German trade unions, this remained a minority position. After the war began, the situation was further complicated by the rejection of Legien's leadership, on the grounds that he was unable or unwilling to exercise his office impartially. ${ }^{8}$

An international trade-union conference in Leeds, Great Britain in July I9I6 (attended by organizations from the Entente countries) laid the cornerstone for an international social-policy programme. The impetus for Leeds was a lengthy document which the leadership of the French Confédération Génerale du Travail (CGT), under its secretary Léon Jouhaux, had drafted in order to comply with the demands of its federation of construction workers that "clauses économiques ouvrières" ["workers' economic clauses"] be included in the peace treaty, thus supplementing the AFL's proposal. The document also made the CGT leadership's position clear with respect to the growing anti-war minority. It was distributed among the CGT membership in February I9I 6 and was published on May I, I916.9 Its premise was that an international social-policy programme needed to be drafted immediately, not after the end of the war.

6. This development is illustrated by, among others: John W. Follows, Antecedents of the International Labour Organization (Oxford, I95 I); Madelein Herren, Internationale Sozialpolitik vor dem Ersten Weltkrieg: die Anfünge europäischer Kooperation aus der Sicht Frankreichs (Berlin, 1993); Ursula Ratz, Sozialreform und Arbeiterschaft. Die Gesellschaft für Soziale Reform und die sozialdemokratische Arbeiterbewegung von der Jabrbundertwende bis zum Ausbruch des Ersten Weltkrieges (Berlin, I980).

7. For the various "trade-union models" see, among others, Jean-Louis Robert et al., L'invention des syndicalismes. Le syndicalisme en Europe occidentale à la fin du XIXe siècle (Paris, I997).

8. In fact there is reason to doubt that Legien was, as he of course vehemently maintained, impartial. (Cf. my remarks in Kurze Geschichte des Internationalen Gewerkschaftsbundes, pp. I 2f.) This is valid independently of the fact that the Entente also would have liked to use the IFTU for its own purposes. It was probably the realization that this was not possible that lead the Entente trade-union federations to demand the headquarters be transferred to a neutral country.

9. See Bernard Georges et al., Léon Jouhaux. Cinquante ans du syndicalisme (Paris, 1962), 
The CGT document stated that the sacrifices of the working class entitled workers to help shape the postwar order, and warned that employers would try to shift the costs of the war on to the workers. It reviewed the development of international labour legislation, going as far back as Robert Owen's attempt to bring about international factory legislation at the Congress of the Holy Alliance in Aachen in I8 18, but referred primarily to international conferences and agreements in the years prior to World War I. In particular the document praised the work of the IALL and its International Labour Office. According to the CGT document, the following issues still had to be resolved: social insurance, limits on working hours, health and safety, labour statistics, and migration.

The fact that the CGT document referred to the work of the IALL and its predecessors (since the international trade-union movement had no clear forerunners on the issues mentioned above) meant that the CGT had "explicitly annexed this tradition as the special preserve of international trade unionism". ${ }^{\text {I0 }}$ Yet, as Jouhaux's biographers noted, the leaders of the CGT "n'avaient jamais attaché un très grand intérêt aux abondants travaux de cette association" [had never shown great interest in the extensive work of this association]. ${ }^{11}$ Nevertheless, these trade-union issues were by no means foreign to the CGT; on the contrary, the CGT rank and file discussed these issues, at times very controversially, and regarded them as requiring urgent resolution. This sense of urgency was heightened not only by World War I, but also by the general awareness that postwar conditions would greatly accelerate a socio-political process, which prior to the war appeared to progress very slowly. Jouhaux's himself might have been influenced by his own experience: As a former worker in a matchstick factory he must have known of the IALL's role in the banning of phosphorus. ${ }^{\mathrm{I2}}$

The international trade-union conference in Leeds, attended by British, French, Italian, and Belgian representatives, met on is July i9i6, parallel to the annual general council of the General Federation of Trade Unions (GFTU). ${ }^{13}$ The main goal of the Leeds conference was still the proclamation of an organizational alternative to Legien, and so to the

pp. 232-235; John N. Horne, Labour at War: France and Britain (Oxford, I99I), pp. 32 I-323. Iо. See ibid., p. 323 .

I I. See Georges et al., Léon Jouhaux, p. 234. The authors add: "Il n'en etait pas de même de certains milieux socialistes ou 'syndicalistes reformistes" " ["He [Jouhaux] was not even part of certain socialist or 'reformist syndicalist' milieus"].

I 2. Ibid.

I 3. The GFTU was formed in I 899 from sections of the Trades Union Congress (TUC), above all to provide mutual support during strikes. Technically independent of the TUC, although its membership associations belonged to it, the GFTU represented the British trade-union movement internationally, e.g. in the IFTU. The TUC itself only became interested in international work during the course of the war and replaced the GFTU in the IFTU in 1919-1920. For this, see Alice Prochaska, History of the General Federation of Trade Unions I899-I980 (London, I982). 
hegemony of the "central powers" in the IFTU. However, the agenda now included the formulation of an international social-policy programme as well, and the CGT document was distributed among the delegates for this purpose. In contrast to the demands that IFTU headquarters be transferred out of Berlin and that an international trade-union conference be held parallel to the peace talks, the international social-policy programme generated no debate and was unanimously accepted. ${ }^{14}$

The delegates to the Leeds conference could not have foreseen how important their programme was to be. After all, due to the limited participation at Leeds, they first had to get the entire international tradeunion movement to accept their programme. Accordingly, Jouhaux, as the conference's appointed corresponding secretary for the Entente organizations, sent a circular containing the Leeds programme to all national tradeunion headquarters. ${ }^{15}$

What were the specific contents of the Leeds programme? It provided that all workers have equal rights, regardless of their place of work; that there be freedom to form unions; that migration be controlled by commissions composed of government, employer, and trade-union representatives; that all immigrants have equal rights and working conditions; and that a comprehensive social-insurance system and an international factory inspection be created. In addition, it provided that working hours be reduced to a maximum of ten hours per day (and to eight hours per day for particularly strenuous jobs), with additional restrictions for women and children; and that there be one-and-a-half days of rest per week. Finally, it provided for an international commission to make proposals at future government conferences - proposals which the International Labour Office in Basle was to ensure were carried out. Nevertheless, decision-making authority remained with governments, in that they were to choose the representatives who passed the resolutions at these conferences. This made it clear that the international trade-union movement could only try to influence proposals in the preparatory stage. At any rate, it was hoped that this would lead to the revival of the movement after World War I. In addition, it was hoped that the social progress achieved in this way would help stabilize the international situation and thus secure peace.

14. See the Report of the Seventeenth Annual General Council Meeting and Conference of International Delegates, Held at the Grand Central Hotel, Briggate, Leeds, on Wednesday, Thursday, and Friday, July sth, 6th, and 7th, 1916 (London, 1916), pp. I-20. The French document was published by the GFTU as a brochure: Historical Survey of the Efforts to Coordinate and Internationalise Labour Legislation. Prepared by the Confederation du Travail, June 1916 (London, 1916). It has been reprinted in Shotwell, Origins, vol. 2, pp. 5-22.

I5. Reprinted in Klaus Schönhoven (ed.), Die Gewerkschaften in Weltkrieg und Revolution 1914-1919 (Cologne, 1983), pp. 246-252 [hereafter Die Gewerkschaften 1914-1919]; and in Shotwell, Origins, vol. 2, pp. 23-26. 
Legien countered the challenge of Leeds by reaffirming his claim to leadership of the IFTU. On 4 October I9I6, he informed all national federations of the Leeds demand that IFTU headquarters be moved out of Berlin and that a corresponding bureau be established under Jouhaux. Since this would circumvent the IFTU's authority, Legien called an international trade-union conference under the aegis of the IFTU, i.e. under his own aegis, for I I December in Berne. ${ }^{16}$ In doing so, he did not address the individual points of the Leeds programme. According to a later account, Jouhaux's circular, due to war-related delays, didn't arrive until the end of October, but was then immediately translated and, although not discussed, shown to German trade-union leaders at a conference on November 21-22. ${ }^{17}$ The report on the conference in the Correspondenzblatt, the organ of the German trade unions, did not contain any information on the Jouhaux circular, much less the text of the Leeds programme. $^{18}$

By contrast, the Scandinavian trade unions had already discussed the text. In fact, at a meeting on 20-2 I October in Stockholm, they rejected the hasty conference that Legien had called to counter the demand to transfer IFTU headquarters. They were concerned that the short notice would prevent a broad spectrum of representatives from attending the conference, and they also demanded a detailed discussion of the Leeds programme, with which they agreed in principle. They made their position clear at a meeting with an IFTU representative in Copenhagen on IO-I I November. The very next day, Legien retracted his invitation for I I December and announced more intensive preparations for a conference at a later date. He now expressly mentioned the need to discuss the Leeds programme. ${ }^{19}$

Legien's tentative reaction was to become only more contradictory. In a February 1917 circular $^{20}$ to IFTU member associations, he argued that Jouhaux's text had been sent to all national headquarters in the name of the Entente organizations' corresponding bureau. He claimed that the General Commission of German trade unions had passed it on to the IFTU (although he headed both organizations at the time!), but that the IFTU didn't recognize the corresponding bureau. He claimed he could not take

16. The letter is in Internationaler Gewerkschaftsbund. Bericht für die Jabre 1913 bis 1919 (Berlin, I9I9), pp. 45f. [hereafter IGB-Bericht 1913-1919].

17. "Bewusste Irreführung", Correspondenzblatt der Generalkommission der Gewerkschaften Deutschlands, no. 46, II/I7/1917 [hereafter Correspondenzblatt]. This article is a polemic by the General Commission of the German trade unions against a leading USPD trade unionist who had accused the commission of trying to keep the Leeds programme secret.

I 8. Correspondenzblatt, no. 49, 2 December 1916. Detailed proceedings of the conference have not survived.

19. The letter is in IGB-Bericht 1913-1919, pp. $46 \mathrm{f}$.

20. Reprinted in Schönhoven, Die Gewerkschaften 1914-1919, pp. 305-3I 2. 
action unless asked to do so by a national federation and that the Scandinavian federations had made such a request at the meeting in Copenhagen. It remained unclear what distinguished the Scandinavians from the German national federation, i.e. why the German national federation couldn't have made the same demand.

In general it appears that Legien was attempting to de-emphasize the leading role taken by the various trade-union federations of the Entente camp in Leeds. Legien was not only concerned here with the organizational challenge to the IFTU's leadership. International conference records show that German trade unions (in particular, Legien) had long pedantically lectured the other organizations ${ }^{2 \mathrm{I}}$ as to how German trade unions represented the height of socio-political progress. This was directed mainly, although not exclusively, at the leftist critics in the syndicalist camp, for example, the CGT. ${ }^{22}$

In February 1917, Legien finished writing the aforementioned circular and his own proposal for a social-policy programme, but then put everything again on hold due to the intensification of the war (submarine warfare). ${ }^{23}$ Only in May, when an international trade-union conference became possible in Stockholm (in connection with a proposed international conference of the socialist parties), did Legien suddenly feel a sense of urgency. At this point, claiming that it was once again "possible to send mail to England and overseas", he sent his documents to the various national trade-union headquarters. They were then published in the Correspondenzblatt along with Jouhaux's text from September I91 $6 .{ }^{24}$

In his circular, Legien not only addressed the entire situation postLeeds, but also, evidently after detailed discussions, took positions on the Leeds programme point-for-point. In general, he agreed with it. Aside from a few minor issues, most of his comments focused on immigration-related problems. Legien stated that they needed to halt all immigration that threatened either trade unions' ability to organize or their social and economic achievements. He was particularly sceptical about recruiting "coloured workers". Legien warned against expecting that that the various social-insurance systems could quickly be brought

2I. Gompers, the American trade-union chairman at the time, has this to say about Legien in his memoirs: "He was German from the tip of his toes to the last hair of his head and assumed a general attitude of German superiority"; Samuel Gompers, Seventy Years of Life and Labor: An Autobiography, 2 vols (New York, I943), vol. 2, p. 39 [hereafter Seventy Years].

22. For the endemic conflict between the German and French trade unions within the IFTU prior to World War I, see: Susan Milner, The Dilemmas of Internationalism: French Syndicalism and the International Labour Movement 1900-1914 (Oxford, 1990).

23. This is the reason given in the article, "Bewusste Irreführung", Correspondenzblatt, no. 46, I7 November 1917 .

24. Correspondenzblatt, no. 21, 26 May 1917. 
into alignment and demanded further restrictions on labour by women and children.

However, he also articulated a perennial problem of international social policy: the demands, this time those made in Leeds, did not go far enough; "They fell far short of providing the protection of the working classes that organized labour has demanded for decades." Many of the Leeds demands, Legien continued, were already realities in some countries; the point was to break the resistance of countries that were "backward in social policy", and to establish international agreement as to a minimum set of demands. Implicit in this proposal, however, was a problem that was to cause constant concern in the future: an internationally binding set of minimum regulations, while improving conditions in some countries, could also roll back advanced social policies already achieved in others.

In his draft, entitled, "Peace Demands of the International Trade-Union Federation" [Friedensforderungen des Internationalen Gewerkschaftsbundes], Legien sought to establish general principles that were detailed and yet avoided measures for individual trades. ${ }^{25}$ His first section provided for freedom of movement on the international job market, though this freedom could be limited by specific government measures (such as in the case of functional illiteracy or economic crises). His draft went on to state that freedom to organize and comprehensive social insurance were to be guaranteed; that no-one was to work more than ten hours in a day; that an eight-hour day was to go into effect for some occupations immediately, and, ten years after the peace accord, the eight-hour day should be established for everyone. Other measures in his draft addressed industrial health and safety, cottage industries, and women and children. His demands did not differ essentially from those of the Leeds programme, although his catalogue was more extensive and was more radical on some individual issues.

Legien's draft, however, clearly differed from the Leed's programme in its detailed section on the realization of international labour legislation. This section expressly provided for a factory inspection in every country, which would include the participation of trade unions. In addition, it gave the International Labour Office in Basle, at which the IFTU was to have an official representative, a comprehensive advisory and supervisory role in international labour legislation, despite the fact that it was ultimately a private institution. The legislation would be passed by regular international conferences composed of government representatives. All of this tended to provide for more internationally binding legislation than the Leeds programme had. 


\section{... AND BERNE ( I 9 I 7 )}

In April I9I7, the international socialist movement proposed the idea of a conference in Stockholm, and Legien sought to use this to set up his own international trade-union conference. Since he was not able to convene it with the help of a trade-union federation from a neutral country (Switzerland), he had the IFTU office in Amsterdam issue an invitation. ${ }^{26}$ However, this detour didn't work either, since the Entente trade-union federations boycotted it, and Legien was left with representatives solely from the Central Powers and neutral countries. This conference was held on 8 June. ${ }^{27}$ There was sharp criticism of the hurried preparations. At the conference the delegates didn't even allow Legien to explain the Leeds programme and the IFTU's counter-proposal. Nevertheless, they expressly recognized the Leeds initiative in that they acknowledged the principle of drawing up an independent social-policy programme (even though it might compete with those of social democratic parties). ${ }^{28}$ They scheduled a comprehensive conference (which was to include representatives from the Entente countries) to discuss and finalize the wording in Berne in the autumn of 1917.

However, before this conference could convene - in the interim the United States had declared war, and the AFL was therefore no longer a "neutral" national federation - the organizations in the Entente camp made their position clear at a conference in London in mid-September I917. ${ }^{29}$ The central issue was participation at the Berne conference. In any event, the transfer of IFTU headquarters out of Berlin was also on the agenda at Berne. Given the difficulty of counterbalancing this with a confrontation with the enemy, the participants in London were unable to reach an agreement. The British and Americans declared from the outset that they would not sit at the same table with the Germans as long as the war continued. Johaux objected just because he thought a

26. Bericht der Zweigestelle Amsterdam des Internationalen Gewerkschaftsbundes vom Dezember 1914 bis März 1919, (no place or date given), p. 8 [hereafter Bericht der Zweigstelle Amsterdam]. After World War I broke out, Legien had, with help of the Dutch trade unions, set up an office headed by Jan Oudegeest, the Dutch trade-union Chairman, in order to have "nonpartisan" contact with opposing trade-union organizations.

27. The proceedings are in Internationaler Gewerkschaftsbund Bericht für die Jabre I9I3 bis 1917 (Berlin, 1919), pp. I2-20 [hereafter IGB-Bericht I9I3-19I7].

28. Legien stated, "When it comes out that the trade-union movement is dealing with questions of social policy, the Socialist peace conferences will be forced to take them into consideration...."; ibid., p. I8.

29. See Conference of Representatives of National Federations of the Trade Unions of the Entente Powers. Held in the Offices of the General Federation of Trade Unions, London, on September Ioth and IIth, I9I7 (London, I917). The German trade unions published a translation: Konferenz von Vertretern der Gewerkschaften der Ententemächte. Abgehalten im Haus der General Federation of Trade-Unions London am 10. und II. September 1917 (Berlin, n.d.). 
transfer was possible. This difference of opinion monopolized a great deal of the conference. By contrast, the Leeds demands elicited no further discussion. They were approved and information was presented on corresponding initial initiatives that had been taken with governments.

At the same time, the AFL representatives also expressed the fundamental misgivings of their organization about any kind of legal and therefore state control of working conditions..$^{30}$ Jouhaux, however, apparently made a convincing objection to the AFL position, which has traditionally been described as "voluntarism". ${ }^{11} \mathrm{He}$ stated that the Leeds programme did not propose specific laws, but rather that laws already in effect in the several countries be standardized so that poorer working conditions in one country could not be used as an argument to defeat demands for better ones in another. The two AFL delegates did not comment on this, but probably remained distrustful of any legislation, including international labour legislation. (In fact, at the AFL convention in November I9I7 this critique of the Leeds programme was again explicitly repeated.) ${ }^{32}$

Nevertheless, the London conference delegates did not dispute that the international trade-union movement should support the general democratic war aims, and they unanimously approved a resolution to this effect. This led to a discussion of the colonial problem, however, which suggested

30. One of the two AFL delegates stated, "We are suspicious of minimum wages and limitations of hours fixed by Government. We have the fear that in these things there is a surrender to the Government, and that something is being done which may react strongly in the future"; ibid., p. 26.

31. Rainer Erd, Die amerikanischen Gewerkschaften im New Deal 1933-1937 (Frankfurt, I986), pp. 33f., describes this conception as follows: "As an organization of qualified skilled workers, the majority of whom were active in the craft trades, the AFL pleaded for restricting itself to working as an autonomous force for unions to attain improved wages and working conditions." This "voluntarism", however, remained within the limits of the capitalist system (where, as Gompers laconically expressed it, one only wanted "more") and thus rejected any socialist- or Marxist-inspired attempt to overcome capitalism.

32. "It is our opinion that the Leeds program is not sufficiently constructive or comprehensive to enable the workers to take best advantage of the opportunity that will come in the Peace Congress. We feel that the Peace Congress will necessarily have to recommend some fundamental proposals for the better organization of international relations in order that in the future there may be some permanent agencies for dealing with the problems that arise in international affairs and to enable the nations to co-operate for the better management of their common interests and their individual needs. Labor is vitally interested in the character and scope of such proposals and cannot afford to neglect the preparation of a concrete program. The Leeds program does not contain suggestions dealing with this broader problem of international organization. Many of the specific articles in the Leeds program are concerned with matters of a legislative nature, many of which in our country come under the jurisdiction of the several states and not of the federal government. For this reason alone, it would be inexpedient, so far as our country is concerned, to have these subjects included in the terms of an international peace treaty"; Labor and the War, pp. 5 If. 
that the motives of the Allies were not so universally democratic after all. In any case, the delegates had once again made it clear that the trade-union movement wanted a voice at the peace talks: either at a congress parallel to the peace talks (the original position of the AFL) or via inclusion in the government delegations (the majority proposal). In the end the AFL delegates endorsed the latter, since the motive for both proposals was the same.

However, the hope that the subsequent conference in Berne on $\mathrm{I}-4$ October $1917^{33}$ could unite the two opposing war camps under the banner of Leeds proved fallacious. On the one hand, as was to be expected, the British, Americans, and Belgians, joined now by the Canadians, announced that they would not send representatives to a Berne conference dominated by the Germans. On the other hand, the French (who had provided the "inspiration" for Leeds) and the Italians failed to attend, although solely because their respective governments refused to issue them with passports. The French in particular had pinned their hopes on attending the Berne conference as they expected to bring about the transfer of the headquarters out of Berlin. To achieve this they had even declared their willingness to exclude discussion of the "question of war guilt", an issue that would certainly have broken up the conference.

As was to be expected, the Berne conference delegates, given the limited participation, deferred discussion of transferring the headquarters until a truly representative conference could be convened. Consequently, "peace demands" became the actual focus of the Berne conference. Stephan Bauer, the director of the International Labour Office in Basle, attended as a guest. The various national federations had submitted changes and additions to Legien's draft, which were discussed by a committee. Unfortunately, the proceedings of this committee have not survived, and thus it is impossible to reconstruct the objections to the draft. The committee spokesman, Wilhelm Jansson, reported only in general terms that most objections raised addressed particular conditions in individual countries. He mentioned only two specific proposed changes: a Dutch proposal that an old-age pension system financed by the state (i.e. by taxes) and one financed by insurance premiums be declared equivalent; and a Swiss proposal that the eight-hour day be proclaimed a general goal. Jansson objected to the latter proposal, arguing that the general goal should first be a ten-hour day, since this would already be a great achievement in many countries. He argued that they should then quickly strive for the eight-hour day, as called for in Legien's draft, and he repeated Legien's aforementioned basic principle of laying down general worker demands, not those of specific trades. 
The full conference then, without further discussion, unanimously adopted a text that was largely identical to Legien's original draft. They added passages regarding cottage industry and the implementation of labour standards, as well as an extra section to establish international maritime labour standards, despite the fact that measures for specific trades were generally not to be included. It was clear, however, that this latter branch of industry was internationally organized and so should be internationally regulated. The only really important addition was a special regulation to ensure equal pay for equal work for both men and women.

In this way, traversing the path from Leeds to Berne, organizations from the two war camps as well as the neutral countries helped legitimate an international postwar social-policy programme. Immediately after the Berne decision, the Austrian delegate, Franz Domes, submitted a request that the IFTU participate at future peace negotiations. In fact, the Leeds and Berne programmes did not differ essentially in orientation. The Berne programme was more comprehensive and contained more binding formulations about enforcement and supervision through an international labour office. However, these differences were only minor variations on a common theme. The German's oft-repeated contention that the Leeds demands did not go nearly far enough ${ }^{34}$ was in the end merely quibbling, which the German IFTU leadership used to conceal the fact that the real issue was war-related competition, i.e. that others had taken the fundamental initiative. This did not, however, prevent the more polished Berne programme from overshadowing the Leeds programme after the war, at least in public opinion. The German leadership under Legien was certainly not opposed to this, and the February 1919 conference in Berne only reinforced this public impression.

In any case, in accordance with the instructions he had received at the conference, ${ }^{35}$ Legien sent the text of the Berne decision to all IFTU organizations on I December I9I7, with the request that the Berne programme be carried out. ${ }^{36}$ The Allied camp did not react, e.g. by reworking the Leeds programme in light of Berne. At the "Inter-Allied Labour and Socialist Conferences" in February and September I918, international social policy was subordinated to general political demands

34. Legien had already stated this in his February I9I7 circular on the Leeds programme [see $n$. 20]. Even more absurd, when one compares the texts, was Jansson's statement at a conference of the German trade-union organizations in July, "the opinion that the Leeds demands are identical to ours is false [...] we cannot accept the particulars of the Leeds programme"; Schönhoven, Die Gewerkschaften 1914-1919, p. 376. Cf. Horne's point of view in Labour at War, p. 326: "Yet for all the nuances of difference, the essential thrust of the German proposals was similar to that of the clause ouvrières adopted at Leeds."

35. The request came from Leipart, Protokoll IBG-Conferenz Bern I9I7, pp. $28 \mathrm{f}$.

36. This is briefly mentioned in, Bericht der Zweigstelle Amsterdam, p. I5. Unfortunately Legien's own report [IBG-Bericht 1913-I9I9] doesn't even mention his letter, much less reprint it. Thus one can only speculate on what it may have said about the Berne decisions. 
for a postwar order, mainly because the national delegations included politicians as well as trade unionists (with the exception of the US delegation, since the AFL had not consented to the participation of the US Socialist Party). At the conferences, social policy was addressed only through the formulation of general principles. AFL President Samuel Gompers, in particular, attached importance to such principles, with his formulation of a general programme, i.e. of a "labor charter". ${ }^{37}$ This charter, however, also reflected the AFL's critical view of international social legislation.

\section{GOVERNMENT REACTIONS}

Immediately after Leeds and Berne, national trade-union federations in both war camps presented their social-policy programmes to their respective governments. For example, the British organization sent the Leeds demands to Prime Minister Asquith on 30 August 1916. It was hoped that these demands would lead to talks among the Allied governments, even though they didn't necessarily intend to initiate a discussion of war aims. They merely reminded Asquith that, in the past, the poor had always paid the price of war, stated that it was time to consider the general good, and awaited an answer. Asquith, however, did no more than briefly confirm receipt of the Leeds programme. ${ }^{3}$ When he was ousted in December 1916, he still had not expressed an opinion on its contents, and his successor, Lloyd George, also did not consider these issues important before the end of World War I.

The German trade unions proved to be more obstinate. After the Berne conference, in November 1917, their General Commission wrote to the German Chancellor and, at the same time, informed members of the Reichstag. ${ }^{39}$ Only at the end of February i9 8 did the German government reply that it was willing to discuss the Berne programme, and even then its willingness may have only been due to the fact that the leftist bourgeois social reformers of the Gesellschaft für Soziale Reform (GfSR) [Society for Social Reform], the German section of the IALL, had adopted the Berne programme. One of the leaders of the GfSR had been a guest at the Berne conference and the GfSR had submitted its own petition to the German Chancellor, although its language was more general and it contained fewer concrete demands. $4^{\circ}$

37. Carol Riegelmann, "War-Time Trade Union and Socialist Proposals", in Shotwell, Origins, where the corresponding resolutions are found in vol. I, pp. 55-79, 68-70, and vol. 2, pp. 52-69, 75-80. See also Horne, Labour at War, pp. 329-33I.

38. The letter and Asquith's brief confirmation of receipt are in General Federation of Trade Unions: Eighteenth Annual Report and Balance Sheet (London, 1917), pp. $23 \mathrm{f}$.

39. This letter is in Schönhoven, Die Gewerkschaften 1914-1919, pp. 382-39I.

40. Ursula Ratz, Zwischen Arbeitsgemeinschaft und Koalition. Bürgerliche Sozialreformer und 
On I8 March 19i 8, the Reich's Office of Economic Affairs [Reichswirtschaftsamt] discussed the Berne programme, without, however, arriving at any concrete results. On the contrary, it was clear that the German government wanted to postpone discussion of the entire matter and avoid taking any official position until after World War I. This did result in sharp criticism from the General Commission of German trade unions and from the GFSR, which the German government simply ignored. ${ }^{4 \mathrm{I}}$ It also ignored criticism that it had missed an opportunity to set an example for social-policy reform in the Brest-Litovsk Peace Treaty, which had been signed with Soviet Russia two weeks earlier. The record indicates only that a GfSR representative made this reproach, but the General Commission of German trade unions had already reminded the German government of the need for including a corresponding section at the end of January I9I 8, when it became known that German industrialists were influencing the Brest-Litovsk peace talks. ${ }^{42}$

Since the aforementioned efforts had not been successful, the General Commission of German trade unions had the German Social Democratic Party bring the matter before the Reichstag. On March 2I, I9I 8, the Main Budget Committee (Hauptausschuss) passed a resolution demanding that a minimum set of social-policy demands be included in a peace treaty. The government representative present stated that the government was sympathetic to the entire matter. ${ }^{43}$ The next day the Reichstag endorsed his statement. ${ }^{44} \mathrm{~A}$ few days later, in a clear reference to the Reichstag decision, the General Commission, in its position statement on BrestLitovsk, once again criticized the lack of social-policy clauses in that treaty. ${ }^{45}$ It is doubtful that Soviet Russia, given the enormous obligations it had to Germany - obligations that were only of secondary importance to

Gewerkschaften im Ersten Weltkrieg (Munich, 1994), pp. 387-392. See also Ewald Kuttig, "German Preparations and Proposals", in Shotwell, Origins, vol. I, pp. 22 I-234.

4I. Jansson, one of the two representatives of the General Commission, wrote a memorandum about this meeting. It is contained in Schönhoven, Die Gewerkschaften 1914-1919, pp. 39If.

42. "Zur Lage", Correspondenzblatt, no. 4, 26 January 1918. Nevertheless, no social-policy issues of any kind were addressed at the peace talks, as is obvious from documentation of the negotiations; see Werner Hahlweg (ed.), Der Friede von Brest. Ein unveröffentlichter Band aus dem Werk des Untersuchungsausschusses der Deutschen Verfassunggebenden Nationalversammlung und des Deutschen Reichstages (Dusseldorf, 1971).

43. Der Hauptausschuß des Deutschen Reichtags 19I5-1918, 4 vols (Dusseldorf, I983), vol. 4, pp. 2080 .

44. Verhandlungen des Reichtags, vol. 3 I I, p. 4570. A specific discussion of this issue did not take place. A few speakers endorsed this point in the context of the general debate on the BrestLitovsk Peace Treaty (as well as on a few riders to it), but more important issues naturally attracted the assembly's attention. Curiously, a report at a conference of German trade-union leaders turned "social-policy" demands in the Reichstag proceedings into "socialist" demands. Had this really been the case, the issue would hardly have been approved by a wide majority of the Reichstag. See Schönhoven, Die Gewerkschaften 1914-1919, pp. $445 \mathrm{f}$.

45. "Frieden im Osten", Correspondenzblatt, no. I3, 30 March I918. 
the German trade-union leadership - could have financed progress in social policy as well. However, as Bieber correctly notes, the German trade unions raised these demands primarily to achieve recognition from the Kaiser's government and so to ensure that their influence was equal to that of German industrialists. ${ }^{46}$

This process was repeated in August I9I8, when the economic supplementary treaties to the Brest-Litovsk peace treaty were finalized. Once again, they contained no social clauses. Once again, the German government struggled to find excuses, this time before a delegation of the General Commission to the German Chancellor. (The delegation had actually been sent to speak about the worsening supply situation.) The government claimed that the haste with which the treaty had had to be concluded meant these issues had been deferred, but that they had not been forgotten, adding that a complete social-policy programme had already been worked out for future peace negotiations. ${ }^{47}$ The General Commission, however, had heard such explanations a number of times before and reacted by uniting with the Swiss trade-union federation to plan an international campaign of public addresses..$^{8} \mathrm{Had}$ this campaign actually taken place, it would undoubtedly have led to an open confrontation with the German government, something which, up to that point, the General Commission had tried its best to avoid. This indicates how much the government's constant evasive tactics must have frustrated the Commission.

At the beginning of October I9I8, in preparation for the imminent German collapse, a German government was formed under Max von Baden (with the direct participation of the Social Democratic Party). This new government made social-policy demands part of its peace agenda, as the German Chancellor announced in his inaugural address on October $5 .{ }^{49}$ With substantial participation by experts from trade unions (including Jansson) and the GfSR, work began on drafting the promised demands and was not interrupted even during the November Revolution. Taking up this draft, the new German government then completed its own draft at the end of December..$^{\circ}$ It was to be published in the German press at the beginning of February I9I9 and then used in the peace talks in slightly modified form.

46. Hans-Joachim Bieber, Gewerkschaften in Krieg und Revolution. Arbeiterbewegung, Industrie, Staat und Militär in Deutschland I9I4-1920, 2 vols (Hamburg, I98I), vol. I, p. 494. Pp. 492-498 provide a general description of the ambiguous position the German tradeunion leadership held on Brest-Litovsk. This position differs starkly from the vehement protests that this leadership under Legien later made against the Versailles treaty.

47. "Die Gewerkschaften beim Reichskanzler", and "Die Sozialpolitik und die Friedensverträge”, Correspondenzblatt, no. 38, 2 I September 1918.

48. See Rechenschaftsbericht der Generalkommission der Gewerkschaften Deutschlands vom I. Juni 1914 bis 31. Mai 1919 (Berlin, I919), p. 193.

49. Verhandlungen des Reichtags, vol. 314, p. 6 I 52.

50. Ratz, Zwischen Arbeitsgemeinschaft und Koalition, pp. 397-399. 
Within the Allied camp work on such a programme had also begun. Already in summer I9I7 the French government had established a committee for this purpose. ${ }^{\text {II }}$ This committee, however, was far from finishing its work by the Armistice and, as a result, was pressured by the French National Assembly. The French committee then worked closely with British representatives. Discussions progressed rapidly, turning to preparations for the imminent peace conference. ${ }^{22}$ Experts from the French section of the IALL, with their long experience in the prewar discussions, played a leading role in this process (whereas the CGT, fully occupied with its growing internal problems, remained virtually outside it). The French could not present a definite proposal, however, until early February I9I9, soon after the special committee created by the Allied Powers had begun discussions. ${ }^{53}$ This proposal provided for internationally binding social standards and for a permanent institution to regulate them.

By contrast, only very elementary preparations had been undertaken in the US. ${ }^{54}$ Experts, primarily from the IALL, had compiled information on the status of social policy for the War Labor Board. However, the position papers based on this information were not finished until January 1919, and so they had to be sent subsequently to the US peace delegation, which had already left for Paris. More so than in the other countries, one expert was largely responsible for the United States' national initiative: James T. Shotwell. He had advised President Wilson since 1917, in particular on social issues, and was now a member of the US peace delegation. Shotwell's expectations, however, were very modest. During the journey to Paris, he drafted a memorandum on child labour, which he expected would be banned by the peace accord, just as the Vienna Congress had once outlawed the slave trade.55 When he arrived in Paris in early January, however, he realized that the international talks had advanced far beyond this stage. With great enthusiasm, he then took up the proposals from other countries and tried to convince Wilson and the rest of the US delegation to adopt them. AFL President, Samuel Gompers, also arrived in Paris in January, not, however, as a member of the US peace delegation, something he had hoped and striven for, but, initially at least, only to participate in discussions with the European workers' movement. ${ }^{56}$ Wilson, however, soon gave him an official mission.

5. The following summary is taken from Charles Picquenard, "French Preparations", in Shotwell, Origins, vol. 2, pp. 83-97.

52. Cf. the documentation of the French preparatory discussions in ibid., pp. 92-108, I16, $\mathrm{I} 3 \mathrm{I}-\mathrm{I} 33$.

53. The French draft of international workers' legislation is in ibid., pp. 323-327.

54. See Leifur Magnusson, "American Preparations", in ibid., pp. 97-105

55. The Autobiography of James T. Shotwell (Indianapolis, IN [etc.], I96I), pp. 95 f.

56. Gompers makes clear in his autobiography (Seventy Years, vol. 2, pp. $476 \mathrm{f}$.) that he was 
The British government had made the most intensive preparations, ${ }^{57}$ despite the fact that, during World War I, it had limited itself mainly to following international social-policy discussions through the Intelligence Division of the Ministry of Labour, and so didn't really begin work on these issues until after the Armistice. At that point, in order to prevent converting the peace treaty into a social-policy agreement, the British government began to consider establishing a special organization, which would take care of international social policy in the future. This would require separate discussions during the peace talks and so, when France indicated agreement, the British formed a separate "labour section" within their peace delegation. Under the leadership of the trade-unionist Barnes, formerly a member of the British Labour Party but now an independent minister, this labour section then began recruiting experts from various ministries.

In early January I9I9 the British transferred their discussions to Paris, where they were able to consult with the French, the US peace delegation, and others. These talks quickly produced several concrete proposals. One was the formation of a permanent international office to host regularly scheduled meetings. This was an improvement on the prewar system, in which conferences were called only after prolonged diplomatic negotiations, which were themselves dependent on fortuitous circumstances. Another problem raised in the talks was how to define a method to ensure the decisions made at these meetings were binding.

How were the representatives to this new international organization to be chosen? As many countries as possible were to be members, although they would not all be equally important. In addition to this, not only governments, but also employers' and workers' representatives had to be taken into consideration. Labour Party and Trades Union Congress representatives now joined the discussion on these issues and together developed the idea of the "tripartite" representation that still characterizes the International Labour Organization (ILO) today. By the end of January I9I9, the British had drafted a detailed proposal that contained a concrete plan for the new institution, as well as minimum social standards. ${ }^{8}$

Already on I 8 January I9I9, at the first session of the peace conference,

disappointed that Wilson did not appoint him to the peace delegation. Other national tradeunion organizations, above all those of the Allied countries, had also hoped to have "workers' representatives" in their countries' official peace delegations. These expectations were also disappointed. See Gerhard A. Ritter, "Einleitung", in idem, Die II Internationale 19I8/1919. Protokolle, Memoranden, Berichte und Korrespondenzen, 2 vols (Berlin [etc.], 1980, vol. I, pp. I-98, I6f. [hereafter Die II. Internationale 19I8/I9I9]. By contrast social democrats and trade unions were represented in the delegations of the former Central Powers. In the end the social democrats were included in the German government in I919.

57. The following is taken from Edward J. Phelan, "British Preparations", in Shotwell, Origins, vol. I, pp. Ios-I 26.

58. A British memorandum on the principles and the first draft of the agreement (dated 2I 
the delegates officially decided to place "international labour legislation" on the agenda. The conference asked all delegations to submit their views on this. In the following days, a British proposal, via official and unofficial discussions, led to the proposal to appoint a special commission to work out a binding agreement. The US delegation proposed an amendment, which was immediately accepted, that the new organization be part of the future League of Nations. The precise composition of the commission was then negotiated and the commission was officially appointed on $3 \mathrm{I}$ January. ${ }^{9}$ It began its work the very next day.

\section{THE BERNE CONFERENCE OF FEBRUARY I 9 I 9}

What possibility of intervention did the international trade-union movement have as of February i919? Its two former war camps had not yet formally adopted a common position. In addition, the demand for an international consultation of the trade-union movement parallel to the postwar peace conference, a proposal that had been supported enthusiastically during the war, now proved difficult to realize.

The problem was that the workers' organizations from the different countries had completely different objectives. Gompers wanted to convene an exclusive trade-union conference. In particular, he wanted it to recreate the IFTU as an organization that would be free of the previous dominant German influence, and that would clearly distance itself from "political socialism". In opposition to this, others, above all the British Labour Party, wanted a mixed social-democratic-trade-union conference. As late as autumn I9I 8, on a visit to England, Gompers had given the impression that he would go along with this.

A detailed description of the development of these competing initiatives does not interest us here. ${ }^{60}$ The end result, however, was that an attempt to hold a conference in Paris failed, because the Allied organizations objected that the presence of German representatives there would cause mass protests. A neutral country, Switzerland, then offered the city of Berne as an alternative location. However, when Gompers arrived in Europe in January I9I9, he had made it clear that the AFL would not attend a conference where "politicians" were present. This led Jouhaux, in the name of the corresponding bureau created at Leeds, to call for special

January I919) can be found in ibid., vol. 2, pp. II7-I25, I38-I40; the 26 January 1919 and 2 February 1919 British drafts can be found in ibid., vol. I, pp. 372-422.

59. Cf. the version in ibid., pp. I24-I26. For the corresponding sections of the minutes: ibid., vol. 2, pp. I26, I4I-I 43 .

60. For a detailed account see Ritter, "Einleitung". For Gompers's point of view, see his autobiography, Seventy Years, vol. 2, pp. 480-485. As he stated on p. 470, he saw the AFL threatened by "Bolsheviks and near-Bolsheviks of all lands". 
trade-union discussions parallel to the "main conference" called by the socialist parties in Berne (whose delegations were supplemented in several cases by trade-union representatives; the CGT, however, did not participate). The letter of invitation stated that this special trade-union conference would address the Leeds programme. ${ }^{61}$

Legien was unable to keep up with these developments. He had energetically defended his right to the IFTU presidency throughout World War I. As early as October 1918, when it became clear that the German collapse was imminent, Legien did everything he could to maintain the initiative. He had Oudegeest of the IFTU's Amsterdam office call an IFTU conference in Amsterdam on March 8, I919. The invitation stated that, in addition to the issues surrounding a reorganization of the IFTU, the conference would address the demands from Leeds and Berne. ${ }^{62}$

Jouhaux's special trade-union conference, however, thwarted Legien's plan. Oudegeest had to attend this conference in Berne, and the conference that Legien had planned for 8 March I9I9, had to be cancelled. Thus, the Berne trade-union conference, held from 5-9 February $1919,{ }^{63}$ was not a legitimate IFTU conference, but the bulk of IFTU member organizations attended. Although German trade unions did participate, Legien himself did not attend. He was undoubtedly aware of how divisive his presence would have been. Led by Gompers, the Americans officially boycotted the conference since it was so close to the political conference. For the same reason the GFTU (the British IFTU member organization) did not send a delegation. ${ }^{64}$ The Belgian trade unions didn't attend either, following the lead of the Belgian Social Democratic Party, which had decided not to take part since the Germans were invited.

The special trade-union conference in Berne addressed holding an official IFTU conference as soon as possible in order to resolve organizational and leadership issues. However, its main item of business was the Leeds or the Berne programme, with delegates from the former Allied camp emphasizing the first, and those from the former Entente camp emphasizing the second.

Some trade-union conference delegates also attended the Berne "political" conference, which was held from 3-10 February 1919. ${ }^{65}$ One

6I. Reprinted in Ritter, Die II. Internationale I9I8/I9I9, vol. 2, p. 770.

62. IGB-Bericht 1913-1919, pp. 62-64; Bericht der Zweigstelle Amsterdam, pp. I2-14.

63. Protokoll der Internationalen Gewerkschaftskonferenz vom 5. bis 9. Februar I9I9 im Volkshaus in Bern (Berne, I919).

64. General Federation of Trade Unions: Twentieth Annual Report and Balance Sheet (London, I919), p. 7. TUC representatives who had come for the political conference, however, also took part in the trade-union conference at times. This was the first indication that, in the following months, the "mother organization" (the TUC) would drive the GFTU out of the international trade-union movement.

65. The proceedings of the political conference are contained in Ritter, Die II. Internationale 1918/1919, vol. I, pp. 179-570. 
of the main items on this conference's agenda was, of course, the reconstruction of the Second International. Even more important were the shaping of the postwar order through the proposed League of Nations and the fundamental question of "democracy or dictatorship?" (i.e. the issue of distinguishing themselves from the Bolsheviks). This conference also took up the issue of influencing international social policy, but not as a main agenda item. Both conferences created separate commissions to address this issue, but these two commissions were linked by the fact that the same person, Wilhelm Jansson of the German trade unions, chaired both of them. In addition, several other delegates were members of both commissions. This ensured that the demands the two commissions formulated would have as similar language as possible. ${ }^{66}$

On 5 February 19I9, the first day of the trade-union conference, Jansson made it clear in his introductory report on the social-policy issue that they had to build upon the Leeds and Berne programmes. He now saw practically no difference between these two programmes, except on the issue of how to regulate migration. ${ }^{67}$ Apart from minor issues, he found two points worthy of further attention. Given the entire international situation, he argued, they had to demand an eight-hour day for everyone. Jansson also stated that the International Labour Office in Basle, whose head, Stephan Bauer, was present as a guest of the conference, should give government and trade-union representatives equal participation in its management. In addition to the International Labour Office, Jansson called for an international labour parliament, also to be composed of an equal number of government and trade-union representatives, to develop international labour legislation. Jansson didn't provide for separate representation for employers, since he clearly saw them as represented by "bureaucrats", i.e. governments. In any case, his proposal was a clear advance on that made in 1917, which had given only government representatives the authority to decide what form international labour legislation would take.

Jouhaux followed up on Jansson's statements in a supplementary report. One issue that he particularly emphasized was the newly incorporated demand for free university education, so that not only "the children of the bourgeoisie", but also promising working-class children could study. However, he also emphasized that they were all merely measures to be taken within the capitalist system, and stated, "Now as always we must pursue our goal of liberating the working class; we must never see bourgeois reform as our salvation."

After a brief discussion, the trade-union conference created a commis-

66. For the details, see ibid., p. 435 .

67. The Leeds programme placed more emphasis on the organization and control of migration, whereas the Berne programme ruled out a general prohibition of migration, but called for limitations under certain conditions. 
sion, which recommended a resolution on 8 February 1919. In the meantime, the conference addressed the main agenda item, the reorganization of the IFTU. The new social-policy programme was drafted in three languages and contained only minor additions. The only important one was a proclamation introduced by Jouhaux, which stated that the programme was the product of discussions of the previous years, that the future labour office should be placed within the framework of the League of Nations, and that the ultimate goal was to move beyond the existing social order.

In the course of discussions on the draft, delegates proposed a series of additions. The conference, however, refused to enter into the details again since this would delay passage of the resolution. It was then passed unanimously, along with Jouhaux's proclamation. Divided into fifteen points, the resolution began with compulsory school attendance for all children. It then included regulations protecting women and children and setting daily and weekly working hours. There were sections on health and accidents; cottage industry; freedom of association; migration; the need for a minimum wage; the introduction of comprehensive social insurance; the creation of international maritime rights; the enforcement of a factory inspection; and, finally, an international labour office and international labour conferences. One important point was that half the participants with voting rights at these conferences were to be trade-union representatives. An even more important point was that the decisions of these conferences were to be "binding in the areas in which they were cognizant". This meant the creation of an international, supranational decision-making body, a logical consequence of the idea behind the League of Nations. As late as I917, the corresponding wording had been much less binding, stating that the resolutions of international conferences should be delegated back to the governments for implementation. The trade-union conference also passed an additional resolution on the proposed League of Nations.

Immediately after the trade-union conference approved the resolution, the "political" conference began the discussion of such a programme. Jansson, who functioned as a rapporteur, presented a text, which proved to be identical to the one passed by the trade-union conference. Again there was only a brief discussion. A series of proposed changes was rejected as not in line with the general intent of the agreement and the text was unanimously approved on 9 February 1919. ${ }^{68}$ This display of unity seemed to indicate that the trade-union movement would be able to have a substantial influence on the peace talks that had already begun in Paris.

68. The debate is documented in Ritter, Die II. Internationale 19I8/I9I9, vol. I, pp. $434-460$. 


\section{THE “LABOUR COMMISSION” OF THE PEACE CONFERENCE AT WORK ${ }^{69}$}

In less than two months, between I February and 24 March I9I9, the "labour commission" appointed by the Allied Powers laid the foundations for the ILO. The commission was composed only of representatives of the Allied Powers, i.e. the USA, Great Britain, France, Italy, Japan, and Belgium, as well as Cuba, Poland, and Czechoslovakia, countries that supported the Allied Powers. Except for a few politicians and one wellknown industrialist, most of the committee members - who brought with them a number of expert advisors - were social-reformist academics of the IALL. They also included a social democratic politician, the Belgian Émile Vandervelde. By contrast, the trade unions had minimal participation. Samuel Gompers did chair the commission, but in no way intended to plead for the Leeds or Berne programmes. The only person connected to the two programmes, Leon Jouhaux, did not arrive until after the Berne conference ended, i.e. after the commission had begun to meet.

The labour commission quickly disposed of procedural matters (choosing a chairman and his deputy, setting up an office, the organizational form of the consultations etc.) and then, at its second session, decided to use the British proposal as its basis. ${ }^{70}$ This was an important preliminary decision, since it meant that the central focus of the commission's work would be the formal structures of consultations, and not the content of the international social policy. This was a decisive difference from the Leeds and Berne conferences, which had emphasized a programme of protection for the working classes - and was certainly made in the expectation that general circumstances would no doubt compel its realization. In any event, the labour commission, however, did not address the issue of content until the end of its discussions and then only as a programmatic declaration of intent, although in the hope that the new labour organization would quickly begin to realize them.

69. The ILO later undertook a fairly accurate reconstruction of the labour commission's discussion based on the minutes of the commission and the notes of the various delegations. This was published in the ILO's Official Bulletin in 1923 and then reprinted in Shotwell, Origins, vol. 2, pp. 49-322 (p. I 49 provides a brief overview of the various delegations' records). Using these documents as a basis, Phelan presents a detailed account, "The Commission on International Labor Legislation", in ibid., vol. I, pp. I27-220. A number of the participants also published more or less detailed memoirs, e.g. Harold Butler, Confident Morning (London, I950), pp. I55176; Emile Vandervelde, Souvenirs d'un militant socialist (Paris, I939), pp. 287-292; James T. Shotwell, At the Paris Peace Conference (New York, 1937); Gompers, Seventy Years, vol. 2, pp. 487-494. Other accounts can be found in Francis G. Wilson, Labor in the League System: A Study of the International Labor Organization in Relation to International Administration (Stanford, CA [etc.], 1934) [hereafter Labor in the League System]; and Antony Alcock, History of the International Labor Organization (New York, I97I), pp. I 8-37. For another perspective on this section, see Jasmien van Daele's article in this issue, pp. 435-466.

70. For the British proposal of February 2, see n. $5^{8 .}$ 
After this fundamental decision about procedure, designated as the first reading, the labour commission took up each article in turn. In this way, a second reading took place until the end of February. The commission members then discussed issues with their respective delegations. On I I March I9I9 there was a third reading. American objections at that reading led to a temporary impasse, but the commission was able to approve a final draft on 24 March. Not all the discussions at the meetings focused on issues of fundamental principles. Many of the changes to the British draft were editorial in nature.

Although it is not possible here to enter into the details, it is worth pointing out that from the beginning no-one contested the structure, the "machinery", of the new labour organization, which consisted of regular (if possible, annual) conferences, attended by representatives from the member countries, and an administrative body, i.e. an international labour office. There were, however, two very controversial points. The first was how a country should be represented. It was clear from the outset that, in addition to government representatives, each country would send employer and worker delegates. This, however, raised the question of how each country's votes were to be allocated among its representatives. Various solutions were suggested, which, for example, distributed votes among delegates in various proportions. In the end, however, these were reduced to two opposing proposals: giving the government representative two votes and the employers and workers delegates one each, or giving all three one equal vote. The intent of the first proposal was to prevent the government representative from being outvoted by the other two delegates, whereas the intent of the second was to keep the government representative in check.

The main proponents of the first proposal were the British and Vandervelde, the Belgian social democrat, whereas Samuel Gompers, in accordance with the AFL's tradition of "voluntarism", did not see any good in government involvement. Later he even accused Vandervelde of having speculated that social democratic governments would soon come to power everywhere and thus give workers a clear majority at the conferences. As Gompers put it, "Their view was egotistical". $7^{\mathrm{I}}$ The CGT also regarded this as deeply offensive to French "traditions of equality", ${ }^{2}$ as Jouhaux made clear in a protest he read during the discussions. Nevertheless, in the end, the labour commission approved giving the government representatives more votes by a slim majority. Regardless of how the votes might have been distributed, the idea that employer and worker delegates would build a solid and permanent coalition against the government representatives proved over the course of the ILO's development to be absurd. On the contrary, on

71. As stated by Gompers in I92 I. Cited by Wilson in Labor in the League System, p. 46. See also Gompers, Seventy Years, vol. 2, pp. 49If.

72. Shotwell, Origins, vol. 2, p. 301 . 
controversial issues that were important for the workers, governments and employers would usually stand together.

The second controversial point was the binding nature of conference decisions. It soon proved to be even more explosive that the first. The tendency of the British draft, with some qualifications, was to oblige the member countries to convert international labour conference decisions into national legislation. France and Italy wanted conference decisions to be even more binding, i.e. virtually automatic. Once again, the US put up resistance, in part due to the AFL's traditional mistrust of national social legislation, but also on constitutional grounds, since in the US the individual states had jurisdiction over social policy. The discussions were nearly broken off at the commission's third reading, ${ }^{73}$ and intensive efforts were required - Shotwell had a decisive role in them on the American side $^{74}$ - to negotiate a compromise acceptable to all. In the end, the commission agreed that the conferences could both reach conventions, which the national parliaments were to convert into legislation, and make recommendations. The labour commission also agreed that federal states could regard conventions as recommendations. Gompers succeeded in adding an important clause preventing conventions or recommendations from lessening existing social legislation on a national level.

These labour commission decisions greatly reduced the possibility, feared by Gompers and others, that the ILO could act as an international social parliament. Not only did they prevent conference decisions from being binding on national parliaments, they also limited the supervision of any resulting national legislation to an investigation and public statement in cases where conference decisions were not applied properly. The commission mentioned possible economic consequences if conference decisions were not converted as national legislation, but, since no clearly defined sanctions were announced, they remained too vague to act as a deterrent. This was to prove the largest, most significant problem for the ILO, and remains so today.

The issue of membership posed a separate, but uncontroversial problem. Should membership be limited to countries in the League of Nations? At issue were Germany and the other countries defeated in World War I, since initially they were not allowed to participate in the League. In the end the labour commission approved admitting these countries, since otherwise the ILO would have remained insignificant. The final decision, however, was left to the Allied Powers.

73. Had this taken place, the US, which in any case later rejected the League of Nations and thus the ILO, would have been responsible for preventing even the formation of the ILO. (The US Senate did not ratify the entire peace treaty. Only in 1934 did the US become a member of the ILO without, however, joining the League of Nations.)

74. For Shotwell's important role in the negotiations, see Harold Josephson, James T. Shotwell and the Rise of Internationalism in America (Rutherford, NJ [etc.], 1975), pp. 86-90. 
Finally, the labour commission's text included arrangements for the first labour conference. For practical reasons, they rejected a proposal to call a conference quickly and then, without much discussion, agreed to a date in October I919, chose Washington DC as the venue, set an agenda, and established an organizational committee.

But what had happened to the specific trade-union programme? After his return from Berne, Jouhaux had put forward that conference's programme and, together with the Italian representatives, argued that the demands in it be made a binding part of the agreement. He was unable to achieve this. The labour commission only inserted another declaration of intent, such as it had already been contained in various memoranda at the beginning of its discussions, and then in the preamble to the commission's text. There it was stated that social justice was to be the basis of peace. The commission now added non-binding "labour clauses" with general statements such as, "labour should not be regarded merely as a commodity or article of commerce". The principles that one should strive for included: the freedom to organize, a living wage, the eventual institution of an eight-hour day, enough time for rest and relaxation, prohibition of child labour, equal wages for men and women, equal rights for all workers in any given country, and the guarantee of a factory inspection.

With this the commission ended its work on 24 March, but not before Gompers had made a final dramatic statement. He told the commission that he had been uncertain whether he could approve the document until the very last minute, but that, after a sleepless night, he would now approve it and undertake a campaign in the US to gain its acceptance there. ${ }^{75}$ The commission's document, however, had still to be submitted for approval at the peace conference. On I I and 28 April I9I 9 it was approved by the full session and incorporated in identical wording in the peace agreements of each of the defeated countries. ${ }^{76}$

The Allied Powers negotiated these peace agreements without input from the defeated countries, which then had to accept them as they were.

75. The minutes as published are unclear on this point. I here follow the version of Phelan, who drafted the English protocol as conference secretary. See Shotwell, Origins, vol. I, pp. I97f. Phelan had this to say about Gompers's position: "It was difficult to avoid the conclusion that his heart had never been wholly in the work. His philosophy of the labour movement, implied in speech after speech, was clearly antagonistic to labour legislation, and the scheme in one work was a scheme to secure labour legislation. [...] Although the members felt deeply the solemnity of his declaration, it is doubtful if they realized how much his decision meant to him, or how real was the opposition he realized he must meet."

76. Phelan, "The Labor Proposals Before the Peace Conference", in ibid., pp. 199-220. The agreement was incorporated as Part XIII of the Versailles Treaty with Germany, as Part XIII of the Treaty of Saint-Germain with Austria, as Part XIII of the Treaty of Trianon with Hungary, as Part XII of the Treaty of Neuilly with Bulgaria, and as Part XII of the Treaty of Sevres with Turkey. 
The agreement with Germany was the most important one. After the German delegation received their agreement in May, they protested it in vain, objecting also to the ILO's section, although it was of course less important than the far more onerous sections on responsibility for the war, reparations, and other matters that cannot be addressed in this article. 77 Legien was a member of the German delegation and was accompanied by several trade unionists from the Christian trade-union federation that did not belong to the IFTU. In a statement that was distributed internationally as a wireless message, Legien attacked the agreement in general and the ILO section in particular, stating that Germany should be allowed to join the ILO immediately, and that the Berne programme should immediately be put into effect. ${ }^{78}$ This was repeated a few days later in the official German counterproposal to the international labour protection programme. The German draft, as did the Berne programme, emphasized "content" over "form", to the point that the future organization itself was of secondary importance. In addition, an international trade-union conference in Paris was called for, to work out the details.

The Allied reaction was brusque. Shotwell noted in his diary that this was "not an honest statement [...]. The Germans, who have just put down radical socialism in a civil war in the streets of Berlin, cannot expect us to take this seriously." 79 The Allies feared that the German government, by mobilizing international labour for more far-reaching demands, wanted to divide them and so overturn the peace agreement. In the following weeks both sides issued a number of statements on the issue. Germany - which in contrast to the Allies had a social democratic government - demanded that the trade unions be given 50 per cent of the votes at the labour conferences,

77. Ewald Kuttig, "German Preparations and Proposals", and "Exchange of Notes", in Shotwell, Origins, vol. I, pp. 221-258. See also Alma Luckau, The German Delegation at the Paris Peace Conference (New York, I94I), pp. 75-77, 188-193.

78. Correspondenzblatt, no. 22, 3 I May i919.

79. Shotwell, At the Paris Peace Conference, p. 3 I 8. Later, in a footnote to Ewald Kuttig's article on the German proposals, Shotwell stated that the ILO principles were not worked out with a view to addressing all trade-union demands, but rather such that the text could be accepted by all governments, including those of the former Central Powers. He wrote, "That the German negotiators should make such far-reaching demands for immediate adoption was unfortunately interpreted by the Allied negotiators as part of a diplomatic move on the part of Germany rather than a real concern for the preparation of a treaty text capable of acceptance and ratification by governments and legislatures. It was interpreted as a bid for labour support in the Allied countries by which public opinion would be divided and German propaganda [would] have greater scope to work. This impression was accentuated by the further demands of the German Delegation referred to here, that the Peace Conference should invite a conference of trade unions to remake the labour section of the Treaty, with the further implication that the resolutions of such a conference should be accepted as binding upon governments"; Shotwell, Origins, vol. I, pp. 242f. However, for a similar opinion by an historian today, see Heinrich Potthoff, Gewerkschaften und Politik zwischen Revolution und Inflation (Dusseldorf, I979), p. 2 Io. 
and that the decisions of those conferences be binding. The German protest, however, achieved nothing, given that the peace agreement was not negotiable. The Germans were simply reminded that the labour conference scheduled in Washington DC was the proper place to discuss concrete workers' rights issues. However, it wasn't at all clear whether the Germans could even attend this conference.

\section{THE IFTU'S RE-FOUNDING CONGRESS IN AMSTERDAM ( 28 JULY - 2 AUGUST i 9 I 9 )}

The delegates to the IFTU re-founding congress ${ }^{80}$ now had to make a decision. Their main task was to overcome the split into the two war camps and to reorganize the IFTU. The two former war camps found themselves reuniting in the process of forging a common position on the ILO. They agreed not only about their participation in the ILO, but also shared a more general stance toward the entire League of Nations. A commission led by Jouhaux and the Dutchman Edo Fimmen (in his first position as an international trade-union leader) introduced a resolution to compare the Berne decisions with the principles in the ILO Charter point-for-point. The perhaps not so surprising conclusion was that the ILO Charter either did not incorporate the Berne decisions, or incorporated them only in diluted form. The commission concluded that the trade-union movement must continue to fight to realize the goals of the Berne conference.

Gompers then introduced a brief counter-resolution, which, without going into the details, stated that the ILO Charter did not always correspond with IFTU demands. Nevertheless, he said that they should begin putting the charter into effect immediately, using the not particularly intelligent argument that Rome wasn't built in a day. Jouhaux and others replied that they had not drawn up a maximum programme in Berne, but rather a minimum one ${ }^{81}$ that could be fulfilled anywhere. We are here, after all, an Austrian delegate added, because we have come to an independent workers' conference. The congress then passed Jouhaux's resolution by a wide majority. Only the British delegation voted for Gompers's resolution. ${ }^{82}$

If the IFTU congress had limited itself to the critique of principles in Jouhaux's resolution, their participation in the Washington labour conference would have been surprising. However, not to participate

80. Bericht über den Internationalen Gewerkschaftskongreß. Abgehalten im Councertgeboww in Amsterdam vom 28. Juli bis 2. August 1919 (Heinschließlich Bericht über die Vorkonferenz, abgehalten am 25., 26. und 29 Juli 1919) (Amsterdam, 1919).

8I. In his welcoming address, the Dutch trade-union chairman Oudegeest had gone so far as to speak of the "socialist and revolutionary character" of the Berne conference; ibid., p. 23.

82. For the corresponding discussion and resolution, ibid., pp. 43-46. 
would have been surprising as well, because this would have run counter to the reformist position that had prevailed in the IFTU since World War I. Probably with this in mind, the commission introduced a separate resolution stating that the IFTU should attend the Washington conference in order to speak in favour of its own more comprehensive demands. However, they made IFTU participation dependent on the following two conditions: All countries were to be represented - here they had the participation of Germany and the other defeated countries in mind - and the workers were to be exclusively represented by the IFTU member organizations. Only if this was accepted, was participation possible. In addition, at the Washington conference, the IFTU delegates were not only to demand that the full Berne programme be realized, but that the ILO be reorganized. They were also to request that workers' and employers' delegates have the same number of votes at the labour conferences as the government representatives (i.e. that each of the three types of delegates have one vote each) and that the decisions of the conferences be more binding.

After this separate resolution was read, Jouhaux called for immediate approval by acclamation. At this point, Gompers, along with the British delegation, once again objected. He argued that the IFTU as such had not attended either Leeds or Berne and so was not bound by the decisions of those conferences. He added that, although they were in agreement that the ILO charter's "labour clauses" were not satisfactory, the IFTU should attend the Washington conference in any case. Legien then replied and a serious argument ensued. The divisions between the former war camps immediately resurfaced, to the dismay of the former "neutral" trade-union representatives. Jouhaux and Legien then also got into an argument, but, in the end, the commission was able to agree by a wide majority on the resolution. Gompers remained alone in his demand for an amendment calling for the elimination of the clauses about the necessary participation of all countries as well as about the binding nature of the guidelines for the IFTU delegates. This led the Scandinavian and Swiss delegates to state after the end of the congress (i.e. it was not recorded in the conference minutes) that, if all IFTU countries were not invited, and if some IFTU member organizations nevertheless sent delegates to Washington, they would have to review their continued membership in the IFTU. ${ }^{83}$

\section{THE WASHINGTON LABOUR CONFERENCE ( 29 OCTOBER-29 NOVEMBER I 9 I 9)}

The newly elected IFTU leadership thus had a binding mission, with which it was almost completely occupied for the next two months. In

83. As reported in Correspondenzblatt, No. 38, 20 September 1919. See also below. 
intensive negotiations with the Allies on the one hand, and the Germans on the other, they were able to gain immediate and unconditional full participation for Germany by the middle of October 1919. ${ }^{84}$ The irony was, however, that the decision came so late that the Germans, who had already chosen a delegation composed of government, employer, and worker representatives, were not able to send that delegation to Washington on time.

During the IFTU leadership's efforts to gain Germany's participation in the Washington conference, the issue of the IFTU being the sole organization representing workers was forgotten. The IFTU refounding congress had made this one of the conditions of IFTU participation in the Washington conference, as compensation, so to speak, for the Berne programme's not being accepted. The Allied representatives, however, had immediately made it clear that no concession could be made here, since this would interfere with the autonomy of governments. In September and October I9I9, the IFTU letters to the Allies addressed only German participation in the Washington conference. (In practice, however, after the Washington conference, the IFTU did represent the workers almost exclusively, although occasionally individual governments made decisions that ran counter to this.)

After the Germany entry into the ILO was quickly confirmed by an overwhelming majority, the delegates to the Washington conference ${ }^{85}$ approved six agreements and six recommendations that included widereaching social-policy regulations. The agreement on the eight-hour day (or a forty-eight-hour week) in particular proved to be of extraordinary symbolic value and seemed to convince all sceptics in the IFTU. The real problem, however, turned out to be the ratification of these agreements and their translation into national laws. The optimism of the delegates at the Washington conference, who believed that ratification would follow within a year, quickly proved to be illusory. In reality, even social

84. For a brief overview, see: Phelan, "The Admission of the Central Powers to the International Labor Organization", in Shotwell: Origins, vol. I, pp. 259-282. For a brief sketch, see Erster Tätigkeitsbericht des Internationalen Gewerkschaftsbundes (Juli I9I9 - Dezember I92I). Vorgelegt dem Ordentlichen Kongreß Rom, April 1922 (Amsterdam, 1922), pp. 27-31. The IFTU archive was lost at the beginning of World War II, but Shotwell copied extensive material from it (as he did from other archives) in the early I930s while writing his history of the development of the ILO. These copies are today kept in the ILO archive in Geneva; the documents relevant to this discussion are filed under the call number 5.20. The ILO archive also contains the records of the organizational committee the Allies created for the Washington conference in April I9I9. These records too contain a great deal of correspondence on the subject at issue (D 600/2/9).

8 5. Harold. B. Butler, "The Washington Conference", in Shotwell, Origins, vol. I, pp. 305-330; and International Labor Conference: First Annual Meeting October 291919 - November 29 1919 (Washington DC, 1919). For the IFTU's view, see: Erster Tätigkeitsbericht des Internationalen Gewerkschaftsbundes I9I9-192I, pp. 3 I-33. 
democratic governments were reluctant to approve an eight-hour day. As a result, the IFTU was not able to celebrate its successful influence on the ILO, but rather had to make "ratification of the Washington workinghours agreement" one of its central campaign themes for the years to come. ${ }^{86}$

As a result, the IFTU concentrated on guaranteeing its own organizational influence and, in the end, this proved to be the real result of its participation in the Washington conference. Since Part XIII of the Versailles Treaty had only very general guidelines on the development and structure of the ILO, the Washington conference delegates established certain precedents. For example, objections to the credentials of delegates - a problem that in the future was mainly to affect workers' delegates - were to be handled by an ILO conference committee and then be discussed in full session. ${ }^{87}$ However, the most important precedent concerned the internal organization of the ILO conferences according to groups rather than national delegations. This was because of the IFTU's decision well in advance to intervene "as a faction". Already, at a meeting in early October 1919, the IFTU Bureau had decided to convene all IFTU delegates for preparatory discussions in Washington, for which the AFL would provide the infrastructure. Once in Washington, they formed a permanent workers' group with a chairman and a secretary and worked out a position for every conference agenda item. ${ }^{88}$ "The government representatives [and employer delegates, one should add, R.T.] adopted the same procedure and thus today, although Part XIII of the Versailles Treaty does not provide for it, the group has become a part of the normal mechanism of ILO conferences." ${ }^{89}$

86. See Lex Heerma van Voss, "The International Federation of Trade Unions and the Attempt to Maintain the Eight-Hour Working Day", in Frits van Halthoon and Marcel van der Linden (eds), Internationalism in the Labour Movement I 830-1940, 2 vols (Leyden [etc.], I988), vol. 2, pp. 518-542. For an excellent case study of one of the main governments involved, see Stephan Grabherr, Das Washingtoner Arbeitszeitübereinkommen von 1919. Versuch einer internationalen Regelung der Arbeitszeit in Europe (Berlin, 1992).

87. Butler, "The Washington Conference", in Shotwell, Origins, pp. 3I 3 f. The conflicts surrounding credentials of delegates soon became an "endemic" problem, and even today is one of the main topics in the literature on the ILO. For example, see the section, "Conflicts Concerning Credentials and Committee Seats", in Torsten Landelius, Workers, Employers and Governments: A Comparative Study of Delegations and Groups at the International Labour Conference 1919-1964 (Stockholm, 1965), pp. 259-520; and the chapter, "Credentials: Procedure and Requirements", in Abdel Karim Tikrit, Tripartism and the International Labour Organization. A Study of the Legal Concept: Its Origins, Function and Evolution in the Law of Nations (Stockholm, I982), pp. I83-246.

88. For the IFTU Bureau meeting, see the copies of the IFTU leadership's correspondence in the ILO archive (5.24. A05; 5.24. A07; 5.24. A०8; 5.24 Ar 4 ).

89. Zehn Jahre Internationale Arbeitsorganisation. Vorwort von Albert Thomas (Geneva, I93 I), p. 47 . 
"Constitutive", however, might be a better word than "normal", since these groups then assumed the fundamental initiative at ILO conferences.

Through its concerted presence at the Washington conference, the workers' group was also able to influence the most important personnel decision in its favour, the choice of director. This decision was to determine the character of the ILO's development. The workers' group's choice of candidate expressed the trade-union movement's disappointment in the entire process, from the way the ILO had been structured to the results of the Washington conference, which they saw as inadequate. The delegates did not choose the Englishman Harold Butler, who had been Barnes's closest collaborator in the formation of the ILO. Butler had also done important groundwork as secretary of the organizational committee and seemed to have his hand in almost everything. In a surprise move, Jouhaux proposed a candidate who wasn't even present at the conference, the French Socialist Albert Thomas.

Thomas had been the French Minister of Armament during World War I and so the rest of the French delegation accepted his candidacy. However, he was, above all, the candidate of the workers' group, due to his many years of activity in the labour movement. Thus he could be expected to be familiar with the subject of the ILO, even though he had not helped establish it. (However, he had been a delegate to the "political" conference in Berne in February, I919.) By contrast, Butler was a career civil servant and so lacked connections to the trade-union "milieu". 90

Thomas, whose final approval was delayed several months, proved to be the ideal director and gave the ILO an independent character, even with respect to the League of Nations. He was able to do this by using his many and varied contacts in the international trade-union movement to bind the IFTU closely to the ILO, even though there was still tension between the two organizations at times. In fact, after his untimely death in 1932, there were never again to be such close ties between the ILO and the IFTU. I cannot assess these organizational ties or the political advantages they provided both organizations here. ${ }^{9 \mathrm{I}}$ However, this close relationship would certainly not have developed without Thomas, particularly since the results of the Washington conference led to fierce criticism within the IFTU. Critics had wanted the conference to call for direct intervention in the world economy. However, they had remained in the minority at the conference and were thus convinced that even

90. Thomas was only provisionally elected director at the Washington conference. His real election came after the conference at the first meeting of the ILO board. See: Procès-verbaux de la première session du Conseil d'Administration du Bureau International du Travail (Geneva, 1920); and Phelan, Yes and Albert Thomas (London, 1936), pp. I3-18. The best biography of Thomas is still B.W. Schaper, Albert Thomas. Trente ans de réformisme social (Assen, 1950). 91. For references and an evaluation, see Goethem, De Internationale van Amsterdam, pp. I $23-$ I24; and Tosstorff, Zur Geschichte des Internationalen Gewerkschaftsbundes, pp. 24-30. 
many of the workers' delegates had been too modest in their demands..$^{22}$ It was necessary to convene a special congress of the IFTU in November 1920 in order to close ranks on this issue. ${ }^{93}$ When Thomas took the podium at the next regularly scheduled IFTU congress in April 1922, only one delegate protested. ${ }^{94}$

\section{CLOSING REMARKS}

Altogether it is important to emphasize that the actual form of the ILO was merely a pale reflection of the demands and expectations that the trade-union movement had formulated during World War I. Rather than "content", the ILO offered only "form". This was first and foremost a consequence of the IFTU's exclusion from the real decision-making process in early I919. The IFTU member organizations' support for the war did not pay off in the sense that the IFTU was recognized as a partner in discussions and decisions. The fact that the US trade unions, represented by Gompers, did participate in this process changed nothing, since they did not want to create an international institution with broad powers. This reflected the AFL's basic mistrust of government intervention in labour matters, for which the phrase "voluntarism" has been coined. Gompers's position bears a curious resemblance to contemporary debates about the developments of the international system and the rejection of a multilateral decision-making structure.

The IFTU, however, quickly reconciled itself with this situation because on the one hand the political climate favourable to more farreaching demands had already begun to change during the course of I919; on the other hand, the global postwar economic upswing ended in I92I. In addition, in I920, the struggle with the communists for hegemony in the trade-union movement began ("Moscow" versus "Amsterdam").95 Thus the IFTU came to see an alliance with the ILO (in particular since Thomas was director of the ILO) as a forum within which as many IFTU demands as possible could be raised and thus brought closer to implementation. Only in the following years did

92. This criticism was made by the Italian workers' delegate in Washington, who, together with the Swiss and Polish workers' delegates, published a statement critical of the IFTU majority. It is printed in L. d'Aragona \& G. Baldesi, Rapporti internazionali (Milan, I92 I), pp. 6, 31. See also, "Rapport de Gino Baldesi délégué de la C.G.T. italienne", in La vie ouvrière, nos 30-32, from 30 January to I 3 February i 920.

93. Bericht über den Außerordentlichen Internationalen Gewerkschaftskongreß. Abgehalten im Holborn-Restaurant, London, 22. bis 27. November 1920 (Amsterdam, I92 I).

94. Bericht über den Außerordentlichen Internationalen Gewerkschaftskongreß. Abgehalten in Rom vom 20.-26. April 1922 im Teatro Argentino (Amsterdam, 1923), p. 63.

95. This was the result of the founding of a communist trade-union international. See Reiner Tosstorff, Profintern: Die rote Gewerkschaftsinternationale 192 I-I937 (Paderborn, 2004). 
it become evident that the ILO was really just a public platform for trade-union demands, not the decisive lever by which they could be realized. By that time, however, the IFTU had become so wedded to working within the framework of the ILO that it did not resume the more campaign-orientated policy it had pursued in the early postwar years. 